$\mathbf{R}_{\text {ESEARCH }} \mathbf{P}_{\text {APER }} \longrightarrow$ FOOD SCIENCE e ISSN-2230-9403 - Visit us :

www.researchjournal.co.in

Volume 8 | Issue 1 | April, 2017 | 105-111

DOI : 10.15740/HAS/FSRJ/8.1/105-111

\title{
Aerodynamic properties of sesame (cv. N-8) as affected by moisture content of seed
}

\author{
M.N. Marathe, R.V. Jaybhaye and P.G. More
}

\begin{abstract}
The aerodynamic properties of crop grains influence the selection of the design and operational parameters of equipment. These properties are crop variety specific and moisture dependent. Measurement of terminal velocity is important to determine other aerodynamic properties. A terminal velocity measuring apparatus with vertical tapering rectangular air duct was developed which can measure velocity from 0 to $15 \mathrm{~m} / \mathrm{s}$. The sesame (Sesamum indicum Linn.) seeds of variety $\mathrm{N}-8$ were dipped in water to obtain test samples of moisture contents $9.50,13.46,18.89,24.17$ and 28.99 per cent. The terminal velocity measured with the newly developed apparatus was found increased from 3.05 to $5.25 \mathrm{~m} / \mathrm{s}$ with corresponding increase in moisture contents from 9.50 to 28.99 per cent (w.b.), respectively. In other aerodynamic properties, the values of drag co-efficient were found decreased from 2.9 to 0.6 and Reynolds number increased from 3939.9 to 11043.6 with corresponding increase in moisture contents from 9.50 to 28.99 per cent (w.b.), respectively. Simple linear regression equations were fitted to the obtained data to predict the aerodynamic properties of sesame seeds.
\end{abstract}

Key Words : Terminal velocity, Properties, Drag coefficient, Reynolds number

How to cite this article : Marathe, M.N., Jaybhaye, R.V. and More, P.G. (2017). Aerodynamic properties of sesame (cv. N-8) as affected by moisture content of seed. Food Sci. Res. J., 8(1): 105-111, DOI : 10.15740/HAS/FSRJ/8.1/105-111.

M.N. MARATHE AND P.G. MORE, Department of Process and Food Engineering, College of Agricultural Engineering and Technology, Vasantrao Naik Marathwada Krishi Vidyapeeth, PARBHANI (M.S.) INDIA

Email : marathemanohar93@gmail.com; pramodonimore@gmail.com 